\section{artelogie}

\section{Artelogie}

Recherche sur les arts, le patrimoine et la littérature de l'Amérique latine

17 | 2021

Transformaciones en Cuba contemporánea: cultura y sociedad

\title{
Exposición: Arqueología del color. David Beltrán. Galería Freijo, Madrid, 13 de junio a 27 de agosto de 2020. Madrid, 2020.
}

\section{Suset Sánchez Sánchez}

\section{CpenEdition}

\section{Journals}

Edición electrónica

URL: https://journals.openedition.org/artelogie/10273

DOI: $10.4000 /$ artelogie. 10273

ISSN: 2115-6395

\section{Editor}

Association ESCAL

Referencia electrónica

Suset Sánchez Sánchez, «Exposición: Arqueología del color. David Beltrán. Galería Freijo, Madrid, 13 de junio a 27 de agosto de 2020. Madrid, 2020.», Artelogie [En línea], 17 | 2021, Publicado el 27 enero 2021, consultado el 15 septiembre 2022. URL: http://journals.openedition.org/artelogie/10273 ; DOI: https:// doi.org/10.4000/artelogie.10273

Este documento fue generado automáticamente el 15 septiembre 2022.

All rights reserved 


\section{Exposición: Arqueología del color. David Beltrán. Galería Freijo, Madrid, 13 de junio a 27 de agosto de 2020. Madrid, 2020.}

\section{Suset Sánchez Sánchez}

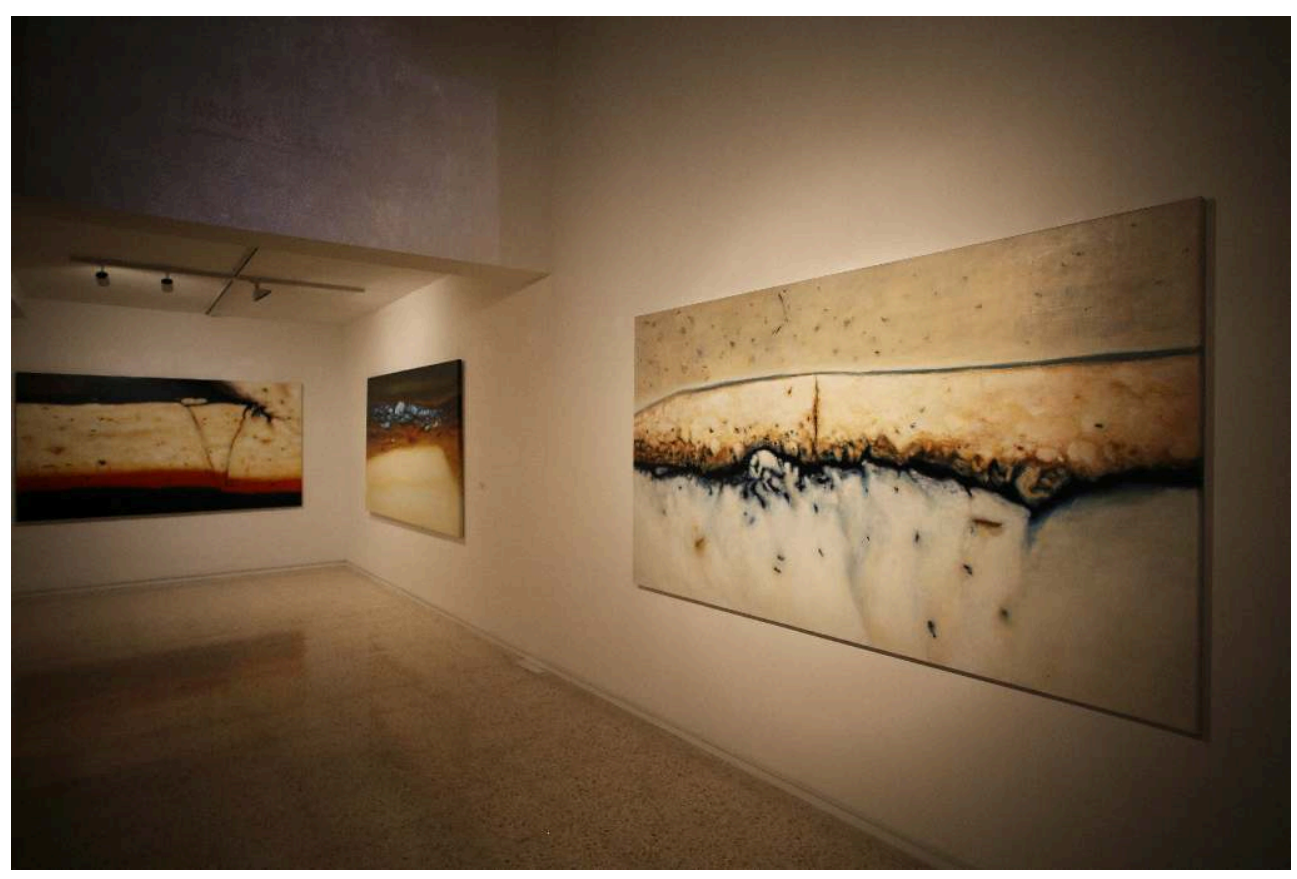

Exposición: Arqueología del color. Vista General.

La historia de la pintura en Occidente ha resultado en la construcción de un relato lineal y cronológico de la sucesión de los estilos y modos de representación de los artistas. Las definiciones y taxonomías de la historiografía tradicional han dado prioridad a aquellos elementos que ahondan en lo representado en la obra, siendo 
categorías como género, tema o motivo las que han primado en el ordenamiento de lo pictórico. Sin embargo, no sería posible pensar esa historia sin la evidente materialidad pictórica, ya que en esencia, y al margen de las interpretaciones de las imágenes, la pintura es un objeto que emerge de la acción de los artistas al depositar pigmentos de color sobre una superficie, componiendo imágenes -figurativas o no- a través de complejas capacidades técnicas aprendidas con el cultivo minucioso del oficio, la téchne.

2 La obsesión moderna por el dispositivo visual ha conllevado en el campo del arte la ausencia o menosprecio de otros modos de "sentir", "oler", "tocar" y "experimentar" la realidad cognoscible que encarnan los objetos estéticos. Si a ello sumamos que la pintura ha sido uno de los pilares de la institucionalización del arte en la modernidad, y que ha quedado confinada en los pesados muros de una entidad grave, de no menor peso que el de sus paredes, como el museo, entenderemos que sus funciones y valores hayan sido fijados en aquellos elementos en los que la mirada ha constituido el vehículo para el diálogo o la relación con la obra de artística. Si a todo ello sumamos el conjunto de normas exhaustivas que estipulan los protocolos de conservación de los bienes patrimoniales, es lógico que el hecho pictórico haya sido limitado a la observación y a una serie de rituales predispuestos en las pinacotecas en tanto espacios en los que persiste y se rinde tributo a la condición aurática de la obra de arte.

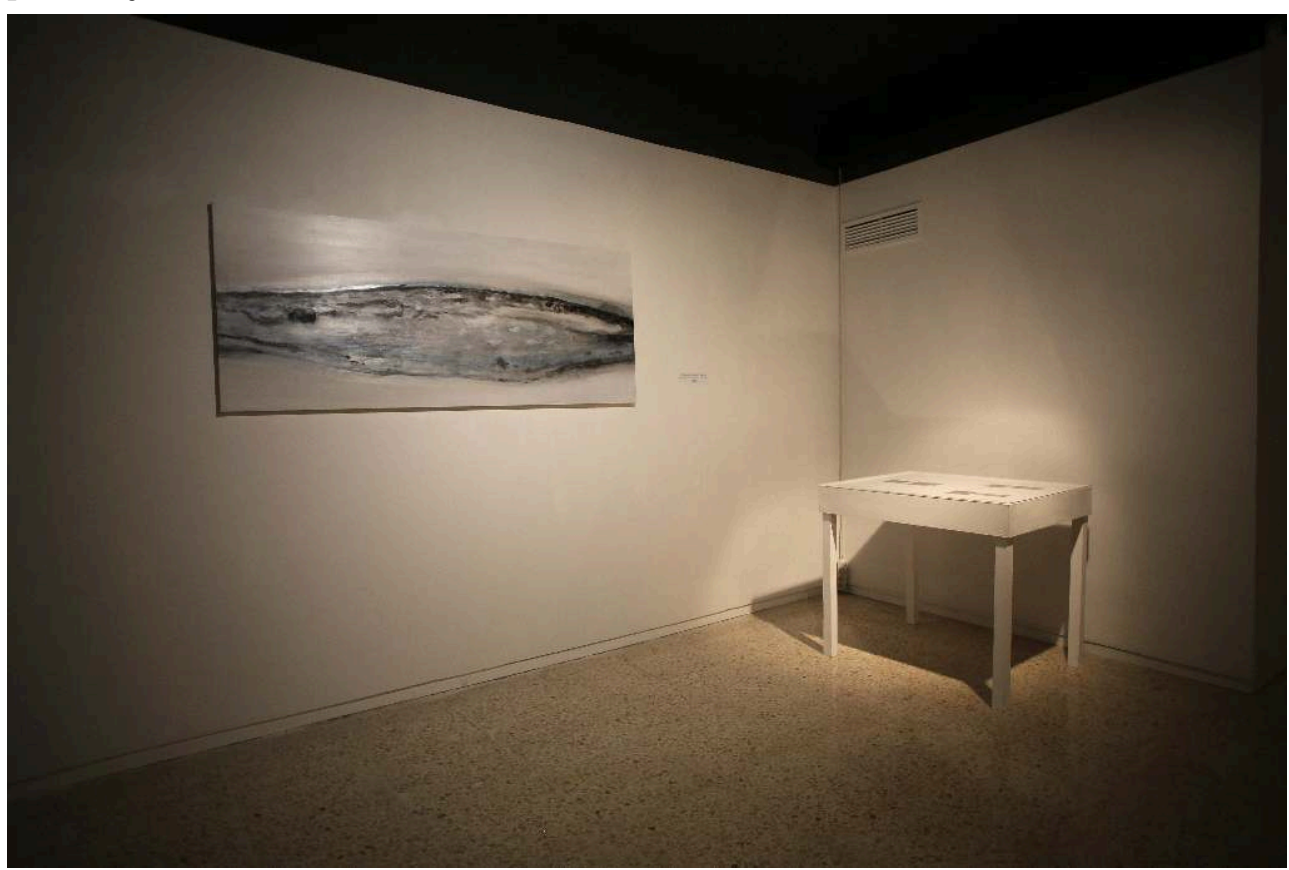

El Suelo de la Maja y la Celestina

3 El trabajo fotográfico, instalativo y pictórico del artista David Beltrán (La Habana, 1978) ha manifestado un insistente empeño por escudriñar esas materialidades que configuran un paisaje alternativo a lo que al ojo humano parece más evidente; es decir, visiones alteradas, fragmentadas, sesgadas, en detalle, que son más esquivas a la simple observación. Las fotografías de Beltrán reparan en una poesía visual donde se condensan las huellas del tiempo sobre la arquitectura, la imprimación de un accidente en la cavidad horadada del asfalto, las formas fractales del óxido sobre el metal expuesto a los caprichos de la climatología en el trópico. La serie Fragmentos de infinito (2006-2016) desatendía cualquier fundamento objetual reconocible a simple vista, desdibujando la docilidad de las formas para cuya inteligibilidad ha sido entrenado el 
ojo. Esa particular fotografía documentaba la realidad extrayendo de ésta la morfología sugerida de las cosas, deshaciendo la totalidad de una imagen que al ser completada termina aprisionando su significado en un catálogo de conceptos estructurados y previamente aprendidos. A través de operaciones de corte, fragmentación, juego de escalas, primeros planos y detalles, Beltrán creaba unas fotografías de naturaleza pictórica; imágenes abstractas en las que líneas, texturas, colores y geometrías varias articulaban la composición abstracta de la obra. Tal es así que algunos críticos han calificado esta serie fotográfica como "peintures trouvées" (MOSQUERA, 2020: p.5) o "pintura encontrada" (LEÓN, 2018: p.32).

4 Esa investigación sobre el asalto visual de la materia que irrumpe de modo inesperado en el campo visual, fue continuada por el artista en la serie de intervenciones públicas Coordenadas paralelas (2014). Entonces, Beltrán sustituía las alegóricas o utilitarias imágenes de las vallas de publicidad comercial y de propaganda política por otros extractos de "realidad", formas abstractas que amplificadas a gran escala introducían un extrañamiento perceptivo en la normalidad cotidiana del paisaje de la ciudad, sorprendiendo al viandante. Este détournement que abre una fisura en la dinámica pragmática de la urbe cosmopolita, donde la señalética y el marketing se orientan a la rentabilidad del trayecto del habitante o el turista, era trocado en la deriva situacionista del artista, que trazaba su propio grafismo en las calles. Esas huellas en formato valla reclamaban la atención del transeúnte, le mostraban una peculiar manera de mirar un lugar como La Habana, carcomida por el salitre del mar que la baña y doliente por las infinitas grietas, descorchados y derrumbes que laceran su arquitectura en ruinas. En esas grandes vallas la fotografía volvía a presentar cierto rictus pictórico, se transformaba en metáfora del estado de ánimo de la ciudad y de su gente, se convertía en paisaje psicogeográfico, en el mapa sensitivo del artista caminante.

El énfasis en la potencia discursiva de la materialidad misma de la pintura, algo que se intuía en las series precedentes ya mencionadas de David Beltrán, quedaría explícito en un conjunto de 2017 llamado Pinturas quemadas. Éstas son piezas surgidas de los vapores, emanaciones, tiznes y manchas impregnados en los lienzos mediante la acción de quemar un color puro al óleo frente al soporte. Algo que es acreditado en los propios títulos de las obras: Rojo bermellón quemado, Azul ultramarino quemado, etc. Pintura informalista, accionismo, nuevo realismo, gestualidad neodadaísta..., con cualquiera de esas clasificaciones podría coquetear el registro en tela del pigmento quemado por Beltrán. Sin embargo, su análisis más radical, sofisticado y conceptual de la pintura estaría por llegar todavía con su siguiente trabajo, iniciado en 2016 y aún en proceso, la serie Arqueología del color ${ }^{2}$. 


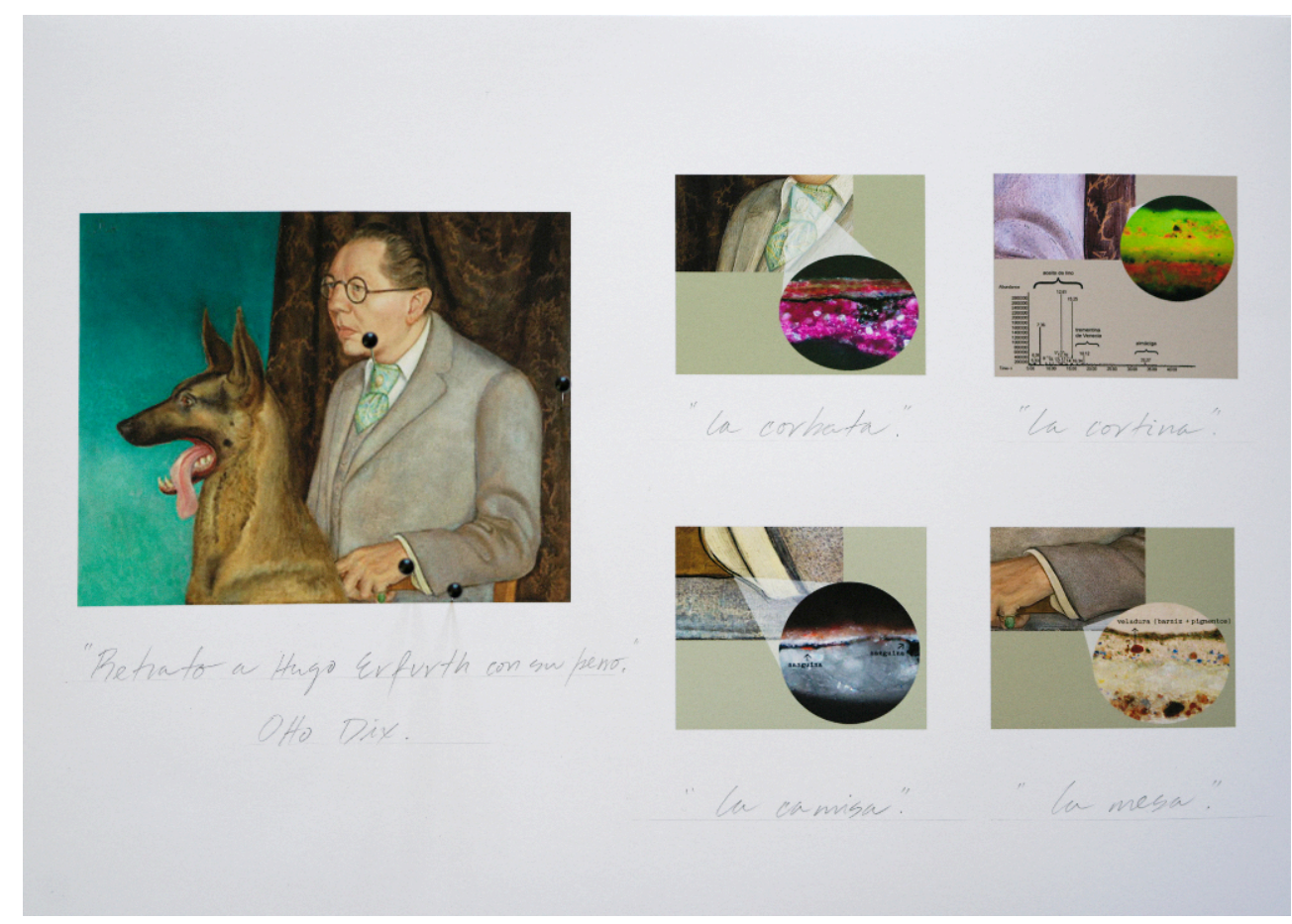

Fotografías Estratigráficas del Retrato a Hugo Erfurth con su perro por Otto Dix

La última exposición personal de David Beltrán en la madrileña Galería Freijo ha devenido en un compendio poético excepcional que recorre el itinerario seguido por el artista durante casi dos décadas de investigación sobre el arte y las técnicas de la pintura en tanto lenguaje y medio de representación por excelencia en la historia del arte occidental. Y justamente, el ademán de distracción que establece esta muestra, nos conduce a una comprensión de la historia del arte, y específicamente de la pintura, a contracorriente de las canónicas narraciones marcadas por la historiografía. Esa otra historia o relato bastardo, si se quiere apócrifo, nos impele a pensar que los imaginarios pictóricos están construidos en base a la posibilidad de existencia de sus materiales y al complejo socioeconómico e histórico que les ha hecho accesibles en determinados contextos de creación y en manos de ciertos artistas. Entonces, ésta es una historia donde ciencia, alquimia, geología, botánica, economía política y sobre todo, la empresa expansionista e imperialista en el sistema mundo moderno/colonial, urden la memoria de las imágenes.

7 Cómo comprender sin esos otros datos que atraviesan tiempos y espacios diacrónicos la policromía de los techos en la Cueva de Altamira; cómo desligar la historia del arte rupestre paleolítico de los ocres de las arcillas con que se han representado las figuras de animales sobre la piedra. Cómo entender si no la elocuencia descriptiva de un término como "atramentum", utilizado para referirse al color negro y las tintas desde la Antigüedad. ¿Acaso son menos importantes y apasionantes que las imágenes legadas por la pintura renacentista las peripecias a través de las cuales llegó el color azul de ultramar a Venecia desde la lejana Asia? Solo algunos pintores elegidos, como Giotto, pudieron hacer uso de ese azul que terminó convirtiéndose en un material codiciado por su alto valor, quedando reservado a los comitentes más selectos. Mientras que el carmín, extraído de la trituración de las cochinillas, era importado desde América y se popularizaba su empleo en la pintura, como evidencian sus característicos tonos en la obra de Tintoretto. 
8 Arqueología del color es un corte en la historia de la pintura, una brecha que permite ubicar el ojo en la materia pictórica para revelar lo que ha quedado oculto bajo la primera impresión y fascinación que ejerce en el espectador lo representado. No en balde el artista utiliza la semántica evocadora del método arqueológico para aludir a su intervención en el tiempo de las imágenes, en su pasado, ese cúmulo de trazas sedimentado durante siglos de sobre-exposición a la mirada que apenas revolotea sobre la superficie del cuadro. Consciente o no de ello, la fisura que es redimensionada en estas "abstracciones hiperreales" - por paradójico que pueda parecer dicho binomiode David Beltrán, da cuenta a través de su sintético procedimiento de la geopolítica de las imágenes, de su condicionamiento histórico-social.

Lo que se ve en las obras que conforman la serie Arqueología del color es una representación exacta y a mayor escala de la imagen fotográfica conseguida a través de un microscopio en un laboratorio de restauración de pintura. Mediante el método de la estratigrafía se ha tomado previamente una pequeña muestra de una sección transversal en obras paradigmáticas de la historia del arte: Cielo de retrato ecuestre (2019), alusiva a la fotografía estratigráfica realizada al Retrato ecuestre de Felipe III, de Velázquez (1634-35), que forma parte de la Colección del Museo del Prado; Estudio de anatomía pictórica: "El Coloso". La piel del Coloso (2018), referente a la obra homónima de Goya datada entre 1808-12, también ubicada en la pinacoteca del Museo del Prado3

El corte estratigráfico arroja importante información sobre la superposición de capas pictóricas en una pieza, las técnicas empleadas, la composición química de los pigmentos utilizados en la realización del cuadro, el estado de conservación del patrimonio, etc. Todo ese complicado proceso de intervención en la materialidad de la pintura queda registrado en un vídeo que, junto a diferentes vitrinas con fotografías de los originales sobre los que se realizó la investigación, documentación y señalización precisa de las zonas de las obras maestras en las que se hizo el corte estratigráfico, aporta un conocimiento que, confrontado a las "abstracciones hiperreales" de Beltrán, ayuda a comprender la trampa de las apariencias en lo que miramos.

11 La poética de David Beltrán ha demostrado recurrentemente una especial sensibilidad para interpelar la materialidad de la pintura. En este punto de su permanente exploración estética parece haber arribado a una clara consciencia sobre el valor de la historia material de la pintura, un tipo de relato que interroga los modos de hacer del oficio de los pintores y que desplaza las cuestiones a dirimir del tradicional ámbito de lo representado. Aquí la duda no consiste en dilucidar o interpretar, en la exégesis del contenido del cuadro, de sus imágenes; sino en desvelar las condiciones de su producción, los rastros de "realidad" acumulados en la superposición y el palimpsesto de los pigmentos, en la transformación de los colores sometidos al paso del tiempo, a la historia de vida de la propia pintura en su tránsito de un espacio de exhibición a otro, de unas manos a otras.

12 David Beltrán extrae de sus catas pictóricas toda la potencia vibrante del color para seducir al público y, una vez conquistada su mirada, susurrarle irónico al oído que las apariencias resultan engañosas. Es ahí, ante el secreto a voces que encierra la exposición Arqueología del color, donde quizás adquirimos plena certeza sobre trompel'œil. De cierto modo, la historia del arte ha consistido en esa sucesiva burla a los sentidos que han conllevado los plurales juegos de la representación pictórica. Ante una muestra como esta, necesitamos desaprender los conocimientos inoculados por la tradición de una disciplina vetusta como la historia del arte, para situarnos en la 
intersección con otras ciencias que nos guíen en el difícil proceso de fijar el ojo en la materia de la pintura.

\section{BIBLIOGRAFÍA}

LEÓN, Glenda (2018), "Pintura encontrada”, en David Beltrán, Maretti Editore, Imola.

MOSQUERA, Gerardo (2020), “Anti-arqueología de la pintura”, en Arqueología del color, Galería Freijo, Madrid..

\section{NOTAS FINALES}

1. Precisamente, entre 2015 y 2017, el artista realizaría una serie denominada Estudio de pinturas encontradas, donde emplearía gestos pictóricos para enfatizar las cualidades visuales de esas fotografías cuya naturaleza pictórica se basa en la mirada profunda e intensiva sobre fragmentos de la ciudad captados a través de la cámara. En este conjunto, la combinación de los medios fotográfico y pictórico materializaría a través del propio soporte intervenido la intersección entre ambos lenguajes sobre la que venía investigando David Beltrán.

2. Las primeras obras de esta serie fueron expuestas en la exposición colectiva Colección de archivo, Museo Nacional de Bellas Artes, La Habana, 2017; y en la muestra individual del artista Azul de composición geométrica, Galería El reino de este mundo, Biblioteca Nacional de Cuba José Martí, La Habana, 2018.

3. Se puede consultar el índice de obras históricas referenciadas en la muestra Arqueología del color en el catálogo de la exposición, en línea: file:///Users/suset/Downloads/ CAT\%C3\%81LOGO\%20DAVID\%20BELTR\%C3\%81N.pdf 